\title{
SOME INVESTIGATIONS ON THE SATURN (HERBICIDE) IN CULTURED COMMON CARP (CYPRINUS CARPIO L.) AT KAFR EL-SHEIKH GOVERNORATE
}

\author{
${ }^{*}$ Gado M. S., ${ }^{* *}$ Ahmed E.K. and ${ }^{* *}$ Abd El-Azzim D. M. \\ ${ }^{*}$ Fac. Vet. Med. Tanta Univ., **Animal Health Research Institute
}

\begin{abstract}
The effectsof carbamateherbicide, Saturn, on the healthstatus of Common carp (Cyprinus carpio L.). Were studied. The LC50 of Saturn herbicide was $9.4 \mathrm{ppm} / 48$ hours. Fish exposed to different concentrations of Saturn (1/2and1/10LC50)for different periods of 7 days and6weeks, respectively;showed nervous and respiratorydisordersmanifested bysurfacing, gasping, rapidopercularmovements and abnormal swimming behaviour.
\end{abstract}

The biochemical functions of the liver; showed significant increase in aspartate aminotransferase (AST), alanine aminotransferase(ALT) and alkaline phosphatase (ALP) activities allover the experimental period.

Histopathological investigations revealed different pathological tissue alterations in both liver and kidneys.

The residual analysis of Saturn in flesh and liver revealed presence of such herbicide in these tissues in different values depending on the used concentration and time of exposure.

\section{INTRODUCTION}

Pesticides constitute now one of the most important chemical pollution problems allover the world, they lead to acute moralities for the exposed fishes and/or impairment of growth and decrease in body weight gain (Mason, 1991 and Ola 1997 ) .

Saturn (S-(4-chlorobenzyl)-N, N-diethyl carbamothioate) is one of the most widely used selective herbicides for controlling the undesirable weeds growing in rice fields allover the world. (Pluta, 1989). 
It had a residual activity for many years, that away from their direct lethal effects on fish health, the suspected accumulation of herbicides residues in the flesh of exposed fishes to sublethal concentration has also, a public health hazards for the human consumers (Mason, 1991).

The present study was planned to investigate the toxic effect of the carbamate herbicide (saturn) on Common carp (Cyprinus carpio L.); Through measurement of medium lethal concentration (LC50) of Saturn herbicide for cultured Common carp, Biochemical investigation of the liver functions after acute and chronic exposure to Saturn. Also, determination of the herbicide residues in different body organs of exposed fish; as well as Studying the histopathological alterations in fish exposed to acute and chronic toxicities of the Saturn.

\section{MATERIALS AND METHODS}

\section{A. Fish:}

A total number of 240 live Common carp (Cyprinus carpio L.) collected form El-Khashaa fish farm at Kafr El-Sheikh governorate were used in the present study.All fish were apparently healthy and with a body weight ranging from $80-100 \mathrm{~g}$ and total length of $12-14 \mathrm{~cm}$. The fish were kept in full glass aquaria supplied with chlorine-free water; two days prior to application of the herbicide(saturn) for acclimatization of fish. Before the experiment; the fish were not fed to avoid excess of excretory matters which may affect the chemical composition of water and to minimize the influence of food on oxygen and blood parameters (Halte, 1986).

\section{B. Chemical used:}

Saturn herbicide; is a carbamate herbicide, S-(4-chlorobenzyl)-N, Ndiethyl thiocarbamate.[Supplied by Egyptian Kafr El-Zayat Pesticide and Chemicals Co.

\section{- Determination of half lethal concentration $\left(L C_{50}\right)$ of Saturn:}

Two trials were designed for determination of the LC50after48 hours in common carp(Cyprinus carpio l.).In pilotexperiment,fish were divided into 5 groups (10 fish in each) to determine 0 and $100 \%$ mortality. 
Further confirmatory experiment was performed as groups of common carp (Cyprinus carpio L.). Were exposed to several concentrations to determine the LC50, while a group was left as a control one.

The determination of LC50 of saturn herbicide was performed mathematically according to Finney (1964). Which depends on the determination of the highest concentration that fails to kill any fish (LC0) and the minimal concentration that kills all fish(LC100). Assessment of the equal dose-response curve was performed according to Dipalma (1982).

\section{Toxicity study: -}

A total number of 110 fish were divided into 2 groups kept under optimal environmental conditions as mentioned before. The fish groups were treated as follows:-

\section{- Group I (Chronic Intoxication, long term exposure):}

This group contains 70 fish; 10 of which were kept as control and the other60fishes were divided into 6 groups in glass aquaria containing 1/10 LC50concentration $(0.9 \mathrm{ppm})$ for six weeks exposure(chronic intoxication).

\section{- Group II (Acute Intoxication, short-term exposure):}

This group contains 40 fish; 10 of which were kept as control and the other 30 fish were divided into 3 groups in glass aquaria containing $1 / 2$ LC50 concentration (4.7 ppm) for one-week exposure.

\section{Biochemical analysis: -}

Aspartate aminotransferase (AST) and Alanine aminotransferase (ALT)were determined by ready-made kits provided by Bio-Adwic,Egypt; (Code No. 80509) according to Reitman and Frankel (1957) and their activities were measured spectrophotometerically at wave length $546 \mathrm{~nm}$.

Serumalkaline phosphatase(ALP)activity was determined according to Bauer (1982) using ready-made kits provided by Bio-Adwic, Egypt; (Code No.83111)and ALP activity was measured spectrophotometerically at wave length $405 \mathrm{~nm}$. 


\section{Residual analysis:}

Theconcentrationlevelsof accumulated Saturnresiduesintheexamined samples were determined by a procedure described by AOAC (1975), in which thoroughly blending homogenized samples (muscles, liver) with known weight.The Saturn was extracted from tissues with acetonitrile, the extract was partitioned with hexane, purified through florisil layer, concentrated and injected to Thin Layer Chromatography (TLC) plates coated with Silica gel.

\section{- Clinical examination of experimental fish:}

Clinical examination of experimental fish was carried out according to the method described byAmlacker(1970).Fish were weighed,measured, then the different body organs were precisely examined for any clinical abnormalities.

\section{- Histopathological examination:}

Samples from liver and kidneys were collected daily for one week from acute intoxicated fish and collected at $1^{\text {st }}, 2^{\text {nd }}, 3^{\text {rd }}, 4^{\text {th }}, 5^{\text {th }}$ and $6^{\text {th }}$ weeks from chronic intoxicated fish.

Tissue specimens were fixed in $10 \%$ buffered formalin solution as the paraffin embedding methods then sectioned at 4-5 microns and stained by Hematoxylin and Eosin stain according to Carlton et al., (1967).

\section{- Statistical analysis:}

The obtained results were statistically analyzed with the student " $t$ " test according to Petrie and Watson (1999).

\section{RESULTS}

Determination of LC50 of saturn in common carp (Cyprinus carpio L.):-

TheLC50for saturn herbicide in common carpwas found tobe9.4 ppm. The Calculation was done as follows:

A Preliminary trial for determination of zero $\%$ and $100 \%$ mortality for saturn herbicide: 
Some Investigations On The Saturn (Herbicide) In Cultured Common ...

Table (1): A Preliminary trial for determination of LC50 of saturn in common carp (Cyprinus carpio L.).

\begin{tabular}{|c|c||c||c||c|}
\hline Conc. (ppm) & Log. Conc. & No. of fish & No. of dead & Mortality \% \\
\hline \hline Control & - & 10 & 0 & 0 \\
\hline 2.5 & 0.39794 & 10 & 0 & 0 \\
\hline 5.0 & $0.69897^{*}$ & 10 & 0 & 0 \\
\hline 14.93 & $1.17397^{* *}$ & 10 & 10 & 100 \\
\cline { 2 - 4 } \cline { 3 - 4 } & 1.20412 & 10 & 10 & 100 \\
\hline 16 & 1.25527 & 10 & 10 & 100 \\
\hline
\end{tabular}

* The highest concentration of saturn which does not kill any fish (LC0).

** The lowest concentration of saturn which kill all fish (LC100).

Determination of LC50 of saturn in common carp (Cyprinus carpio L.).

Table (2): A Preliminary trial for determination of LC50 of saturn in common carp (Cyprinus carpio L.).

\begin{tabular}{|c|c|c|c|c|c|}
\hline $\begin{array}{l}\text { Conc. } \\
\text { (ppm) }\end{array}$ & $\begin{array}{l}\text { Log. } \\
\text { Conc. }\end{array}$ & $\begin{array}{c}\text { Log. conc. } \\
\text { Interval }\end{array}$ & $\begin{array}{l}\text { No. of } \\
\text { fish }\end{array}$ & $\begin{array}{l}\text { No. of } \\
\text { Dead }\end{array}$ & $\begin{array}{c}\text { Mortality } \\
\%\end{array}$ \\
\hline Control & - & - & 10 & $\overline{0}$ & $\overline{0}$ \\
\hline $5.0 *$ & 0.69897 & 0.095 & 10 & 0 & 0 \\
\hline 6.22 & 0.79397 & 0.095 & 10 & 1 & 10 \\
\hline 7.7 & 0.88897 & 0.095 & 10 & 3 & 30 \\
\hline 9.6 & 0.98397 & 0.095 & 10 & 5 & 50 \\
\hline 11.9 & 1.07897 & 0.095 & 10 & 7 & 70 \\
\hline $14.93 * *$ & 1.17397 & 0.095 & 10 & 10 & 100 \\
\hline Sum & & & & 26 & \\
\hline
\end{tabular}

$\log \mathrm{LC} 50=0.97447$

LC50 (antilog) $=9.429095 \mathrm{ppm}$

* The highest concentration of saturn which does not kill any fish.

** The lowest concentration of saturn which kill all fish.

Table (3): The effect of Saturn herbicide on some serum enzymatic activities $(\mathrm{u} / \mathrm{l})$ in common carp (Cyprinus carpio L.) after exposure to Saturn by conc. of $4.7 \mathrm{ppm}$ for 7 days $(\mathrm{n}=5$, mean \pm S.E.).

\begin{tabular}{|c||c||c||c|}
\hline $\begin{array}{c}\text { Duration } \\
\text { (days) }\end{array}$ & AST & ALT & ALP \\
\hline \hline 0 & $29.23 \pm 0.73^{\mathrm{A}}$ & $21.84 \pm 0.57^{\mathrm{A}}$ & $82.44 \pm 1.99^{\mathrm{A}}$ \\
\hline 3 & $39.7 \pm 0.62^{\mathrm{aB}}$ & $33.87 \pm 0.68^{\mathrm{aB}}$ & $95.84 \pm 2.05^{\mathrm{aB}}$ \\
\cline { 2 - 4 } & $43.2 \pm 0.66^{\mathrm{abC}}$ & $40.2 \pm 0.65^{\mathrm{abC}}$ & $105.6 \pm 1.85^{\mathrm{abc}}$ \\
\hline 5 & $65.9 \pm 1.23^{\mathrm{abc}}$ & $63.58 \pm 0.98^{\mathrm{abc}}$ & $119.85 \pm 2.15^{\mathrm{abc}}$ \\
\hline 7 & $14.652^{*}$ & $13.258^{*}$ & $19.658^{*}$ \\
\hline
\end{tabular}

* Significant at $\mathrm{P}<0.05$ using ANOVA test.

$\mathrm{Aa}, \mathrm{Bb}$ andCcsignificantly difference against capital litter at $\mathrm{P}<0.05$ using Least Significant Difference (LSD) as comparative of means.

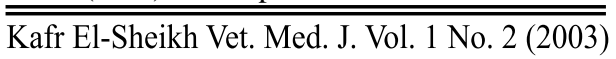


Gado M. S, et. al.

Table (4): The effect of Saturn herbicide on some serum enzymatic activities (u/l) in common carp (Cyprinus carpio L.) after exposure to Saturn by the dose of $0.94 \mathrm{ppm}$ for 6 weeks $(\mathrm{n}=5$, mean \pm S.E. $)$.

\begin{tabular}{|c|c|c|c|}
\hline $\begin{array}{c}\text { Duration } \\
\text { (weeks) }\end{array}$ & AST & ALT & ALP \\
\hline 0 & $29.23 \pm 0.73^{\mathrm{A}}$ & $21.84 \pm 0.57^{\mathrm{A}}$ & $82.44 \pm 1.99^{\mathrm{A}}$ \\
\hline 1 & $31.5 \pm 0.54^{\mathrm{aB}}$ & $27.8 \pm 0.81^{\mathrm{aB}}$ & $91.85 \pm 1.84^{\mathrm{aB}}$ \\
\hline 2 & $37.8 \pm 0.67^{\mathrm{abC}}$ & $32.5 \pm 0.81^{\mathrm{abC}}$ & $99.8 \pm 1.65^{\mathrm{abC}}$ \\
\hline 3 & $45.8 \pm 0.98^{\mathrm{abcD}}$ & $44.9 \pm 1.02^{\mathrm{abcD}}$ & $108.7 \pm 1.18^{\mathrm{abcD}}$ \\
\hline 4 & $51.6 \pm 1.02^{\mathrm{abcdE}}$ & $53.8 \pm 0.71^{\mathrm{abcdE}}$ & $117.8 \pm 2.01^{\mathrm{abcdE}}$ \\
\hline 5 & $62.5 \pm 1.06^{\mathrm{abcdeF}}$ & $66.8 \pm 0.98^{\text {abcdeF }}$ & $127.9 \pm 2.16^{\mathrm{abcdeF}}$ \\
\hline 6 & $73.5 \pm 1.23^{\text {abcdef }}$ & $72.5 \pm 1.25^{\text {abcdef }}$ & $136.9 \pm 1.85^{\text {abcdef }}$ \\
\hline F-calculated & 9.854* & $12.654 *$ & $16.9854^{*}$ \\
\hline
\end{tabular}

* Significant at $\mathrm{P}<0.05$ using ANOVA test.

$\mathrm{Aa}, \mathrm{Bb}, \mathrm{Cc}, \mathrm{Dd}, \mathrm{Ee}, \mathrm{Ff}$ significantly difference against capital litter at $\mathrm{P}<0.05$ using Least Significant Difference (LSD) as comparative of means.

Table (5): The Saturn residues in tested organs(ppm)in common carp (Cyprinus carpio L.) after exposure to Saturn by conc. Of $4.7 \mathrm{ppm}$ for 7 days $(\mathrm{n}=$ 5 , mean \pm S.E.).

\begin{tabular}{|c|c|c|c|c|}
\hline & \multicolumn{3}{|c|}{ Days of Treatment } & \multirow{2}{*}{ F - calculated } \\
\hline & 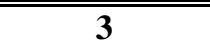 & 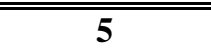 & $\overline{77}$ & \\
\hline Liver & $1.084 \pm 0.012$ & $1.351 \pm 0.055$ & $1.667 \pm 0.051$ & $4.264 *$ \\
\hline Muscle & $0.145 \pm 0.005$ & $0.185 \pm 0.008$ & $0.198 \pm 0.007$ & 0.9854 \\
\hline
\end{tabular}

Table (6): The Saturn residues in tested organs (ppm) in common carp (cyprinus carpio L.) after exposuer to Saturn by conc. Of $0.94 \mathrm{ppm}$ for 6 weeks $(\mathrm{n}=5$, mean \pm S.E. $)$.

\begin{tabular}{|c|c|c|c|c|c|c|c|}
\hline & \multicolumn{6}{|c|}{ Weeks of treatment } & \multirow{2}{*}{ F-calculated } \\
\hline & $\overline{1}$ & 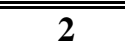 & 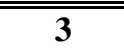 & 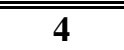 & 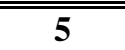 & 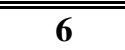 & \\
\hline Liver & $\begin{array}{c}0.875 \pm \\
0.012\end{array}$ & $\begin{array}{c}0.985 \pm \\
0.013\end{array}$ & $\begin{array}{c}1.135 \pm \\
0.016\end{array}$ & $\begin{array}{c}1.354 \pm \\
0.018\end{array}$ & $\begin{array}{c}.547 \pm \\
0.013\end{array}$ & $\begin{array}{c}.612 \pm \\
0.021\end{array}$ & $3.2658^{*}$ \\
\hline Muscle & $\begin{array}{c}0.087 \pm \\
0.005\end{array}$ & $\begin{array}{c}0.099 \pm \\
0.006\end{array}$ & $\begin{array}{c}0.108 \pm \\
0.008\end{array}$ & $\begin{array}{c}0.125 \pm \\
0.011\end{array}$ & $\begin{array}{c}0.151 \pm \\
0.022\end{array}$ & $\begin{array}{c}0.161 \pm \\
0.034\end{array}$ & $4.625^{*}$ \\
\hline
\end{tabular}

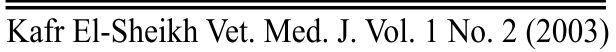




\section{Residues of saturn herbicide in flesh and liver of exposed common carp:-}

Residues of saturn herbicide were determined in flesh and liver of exposed common carp at the end of one week exposure to $1 / 2$ LC50 of saturn $(4.7 \mathrm{ppm})$ showed increase in both flesh and liver through the 7 days of exposure (Table, 5). Residues of saturn in flesh and liver of exposed common carp at the end of the 6 week post exposure to1/10LC50 of saturn $(0.94 \mathrm{ppm})$ were significantly increased gradually through the experimental period (Table, 6).

\section{Results of histo-pathological changes in common carp exposed to saturn herbicide:-}

Histopathological examination of liver and kidney, of common carp exposed to $1 / 2$ LC50 for 7 days or 1/10 LC50 for 6 weeks showed severe to moderate pathological alterations depending on the conc. and time of exposure.

The acute toxicity in the liver sections showed (fig. $1 \mathrm{a} \& \mathrm{~b}$ ); That the central veins, sinusoids and portal blood vessels appeared congested and engorged with blood accompanied areas of haemorrhages dissociating hepatocytes from each others. The hepatocytes were swollen and suffered from different degenerative changes as granulation and vaculation of their cytoplasm.In the kidneys(fig. 1c\&d), the renal blood vessels were congested and engorged with blood associated with areas of haemorrhages in interstitial tissue. The epithelial lining of renal tubules were suffered from cloudy swelling and vacuolar degeneration.

The chronic toxicity in Liver showed congestion of central veins, sinusoids and portal blood vessels began to disappear. The only pathological changes observed in liver were enlargement and presence of eosinophilic granules in the cytoplasm of most hepatocytes (Fig. 2a). Kidney the kidney showed signs of interstitial nephritis manifested by presence of aggregation of macrophages and lymphocytes with focal aggregation of melanophores in interstitial tissue inbetween renal tubules in some cases. Hyaline cast and vaculoation of the epithelial lining of some renal tubules were evident in most examined case (Fig. 2b). 


\section{DISCUSSION}

Saturn has lethal and toxic effect at certain dose levels and is considered as toxic hazard to the aquatic environment.

LC50of Saturn was estimated in Common carp(Cyprinus carpio L.). The obtained results showed that the LC50 of Saturn was found to be 9.4 $\mathrm{mg} / \mathrm{l}$. This result wascompared with that mentioned byShaaban et al.(1980) who reported that the LC50 of Diquat herbicide on Tilapia nilotica was 200 ppm,

As the purpose of toxicity testing is to decide whether a compound is safe or not and detecting the toxic hazard of exposure taking in regard the sensitivity of fish to any aquatic pollution. Safety evaluation studies are used to define the potential of a compound to cause damage, and from this information reducing the concenteration causing such effect.

The LC50 has been defined as being a numerical index that gives some information about the acute toxicity of a chemical substance in experimental fish. The definitive LC50 is a best stimulate with statistically established confidence limits (Balls et al., 1983). At this dose level death is rapid simulating what happens in field condition as result of short term exposure to sublethal or lethal concentration (Kaloyanova and El-Batawi, 1991).

The main clinical signs demonstrated in the common carp (Cyprinus carpio L.) exposed to Saturn were in the form of respiratory and nervous manifestations represented by asphyxia and abnormal swimming behavior. These observations could be attributed to the inhibitory action of the Saturn on the respiratory enzyme system; That may lower the oxygen tension; which is considered as stress that activates the hypothalamus-hypophysisadrenal endocrine system and stimulate the autonomic nervous system (Faisal et al., 1988).

In consequence high levels of corticosteroids and catecholamines in fish blood negatively affect the process of lymphopoiesis and interfere with the synthesis of ascorbic acid (Fry, 1969; Mayer, 1970; Plumb et al., 1976; Peters, 1977 and Mazeaud, 1977).

Concerning the biochemical changes in the fish blood;Saturninduced nephrotoxicity and hepatic injury. The susceptibility of the liver and kidney to toxic insault is usually related to the role they play in biotransformation and disposition of xenobiotics.Extrahepaticmetabolismof toxin byOxidases may affect the target organ and potentiate hepatotoxicity and nephrotoxicity of given xenobiotic (Miyai, 1991 and Kaneko et al., 1997).

$\overline{\text { Kafr El-Sheikh Vet. Med. J. Vol. } 1 \text { No. } 2 \text { (2003) }}$ 
The changes in the biochemical parameters, measured in biological fluid, may often be among the more sensitive indicators of early changes due to the hazardous exposure to insecticides (Heath et al., 1987; AboHegab et al., 1989 and Safi, 1996).

Serum AST and ALT occurs in most cells, however they are useful in evaluating hepatocellular and muscular injury because of the high activity in these tissues (Kaneko et al., 1997). From the present investigation, it was noticed that Saturn at both concenterations (4.7 PPM for 7 days and 0.9 PPM for 6 weeks) induced a high significant increase in the activities of aspartate aminotransferase (AST); alanine aminotransferase (ALT) and alkaline phosphatase (ALP) all over the experimental periods; taking in consideration that this effect was dose and time dependant.

Similar to this observation, a significant elevation in serum enzymatic activities of AST, ALT and ALP was reported by Shehata et al.(1985) in Tilapia nilotica exposed tomolluscicide baylusid,Moussa et al.(1994)who noticed an increase in the serum ALT and AST level of catfish (Clarias lazera) after 48, 72 and 96 hours of bayluscid exposure and Ola (1997) who recorded that the liver and kidney function of common carp exposed to $1 / 2$ LC50 (0.185 ppm) of Bayluscid for 7 days showed slight decrease followed by increase in AST value, significant increase in ALT activity, significant decrease followed by increase in ALP activity. In common carp exposed to 1/10 LC50 (0.037 ppm) of Bayluscid for 4 weeks significantincrease in AST, fluctuations inactivity of ALT, high significantincrease followed by decrease in ALP activity were recorded.

The results of hepatic damage in tested fish, were coincided by the histopathologiocal observations mentioned by Hansen et al. (1971) in pinfish (Lagodon rhomboids) and spot (Leiotomus xanthurus) exposed to polychlorinated biphenyl aroclor 1254; Couch (1975) in fish exposed to polychlorinated niphenyls; Shaaban et al. (1980) in Clarias lazera and Tilapia nilotica exposed to Diquat herbicide;Sastry and Sharma (1981) in freshwater teleost(Ophiocephalus punctatus)exposed to $0.4 \mathrm{mg} / \mathrm{L}$ diazinon and Nafady et al. (1986) and Marzouk and Bakeer(1991)in Oreochromis niloticus; intoxiciated with bayluscide. Similarly,Cruzet al.(1988)showed that liver of fish exposed to $5 \mathrm{ppm}$ Aquatin for 24 hours had extensive necrotic hepatocytes. Fish exposed to $4 \mathrm{ppm}$ aquatin showed fibrosis and congestion of sinusoids. Fish that survived after 96 hours of exposure in 1ppmaquatinexhibited vacuolation of hepatocytes and sinusoidal congestion.

$\overline{\overline{\text { Kafr El-Sheikh Vet. Med. J. Vol. } 1 \text { No. } 2 \text { (2003) }}}$ 
The authors added that liver of fish exposed to 0.5 ppm and 0.3 ppm Brestan (BTN)showed necrosis of hepatocytes and loss of cellular outline. Pyknotic nuclei and fibrotic tissue were abundant furthermore. Johnson (1988) showed that liver parenchymal necrosis, congestion,loss of hepatic muralia and fibrosis are non specific liverlesions associated with pesticide toxicity. Abd El-Nasser et al. (1991) reported the toxopathological changes in the liver of Tilapia exposed to primior and Nuvacron or the mixture of both. In the early stage (first and second weeks). At the end of the third week prominent vacuolar degenerative changes were observed in hepatic cells. These vacuolar changes were of focal distribution. In addition congestion and erythrocytic haemolysis in the blood vessels and sinusoids were seen. At the fourth week, necrosis of the hepatic cells was prominent along with the other changes previously observed in the liver. Marzouk and Bakeer (1991) described the histopathological alteration in the tissue of fish died 2 hours after exposure to high concentration of bayluscid $(0.7 \mathrm{mg} / \mathrm{l})$. The liver showed granular and vacuolar degeneration of hepatocytes. On other hand, the histopathological changes in Nile tilapia exposed to sublethal concentration $(0.4 \mathrm{mg} / \mathrm{l})$ for 4 days were severe vacuolar degeneration with rupture of hepatocytes and extravasation of red blood cells associated with brown pigmentation.El Swak et al. (1992) recorded the effect of ametryne at doses of ( $1 \& 2 \mathrm{mg} / \mathrm{l})$ for 1,2 and 4 weeks on common carp fish (Cyprinus carpio L.). Liver showed congestion, haemorrhage and degenerative changes in hepatocytes with extensive areas of fatty change. Eissa and Fatma (1994) observed congestion in liver of catfish (Clarias lazera) exposed to Ametryne (herbicide). Also, Ola (1997) observed that common carp exposed to bayluscid showed pathological lesions in the liver in the form of multiple vacuoles with smooth edges in hepatocytes. Nucleus revealed pyknotic changes.

Liver of vertebrates generally and fish particularly is the principal organ of detoxification and is the potential site for lipid deposition (Freeman et al., 1983). So exposure of fish to any toxic substance give its indicator on liver which is the site of detoxification of any toxic substance enter the body. The elevations in the activities of AST and ALT recorded in the present investigation may be attributed to hepatitis occurred due to saturn (Meyer et al., 1992; Evans, 1996 and Parums, 1996).

In any form of liver disease associated with necrosis of the hepatic tissues (as with drugs, pesticides or chemicals induced injury),serum AST 
and ALT levels are elevated even before clinical signs of the disease appear (Zimmerman and Henry, 1989; Linne and Ringsrud, 1992). Elevations of these enzymes in blood have been used as an indicator of altered permeability of plasma membrane and/or cellular damage (Dortman and Lawhorn, 1978). Tressler (1988) mentioned that elevation in serum AST results from conditions causing injury to cardiac muscles, hepatic tissue and skeletal muscles cells, but ALT levels increased essentially with liver disease(Kachman and Moss, 1976). However, according to Henry (1979), the elevation of AST and ALT, along with the elevation of ALP activities may reflect some necro-inflammatory disease of the liver (Henry, 1979 and Varley et al., 1980).

The measurement of pesticide residues in various tissues (liver, and muscles of fish) are very important to public health (Johnson et al., 1993 and Garcia-Repetto et al., 1995).

Regarding saturn residues the present results verified retention of saturn in liver and muscles. The preference of it for various tissue was established as liver $>$ flesh at both dose levels of exposed common carp during the exposure to $1 / 2$ LC50 of saturn 4.7 ppm for 7 days and $0.9 \mathrm{ppm}$ for 6 weeks showed significant increase gradually through the experimental period which appear to be dose and time-dependant.

Organophosphorus pesticides persist only slightly in the environment and in the tissues of living organisms (W.H.O., 1985). The persistence of saturn may be attributed to limit elimination and/or biotransfortmation of saturn in body and its distribution in organs despite the rapid hydrolysis of organophosphate in vitro (Anees, 1975). The highest concentration of saturn was noticed in kidney, liver followed by muscles, these results indicated that saturn has high lipid solubility and deposits in fat tissue.

Liver is the site of biotoxication in the body so, the residual concentration have shown to be increased with increasing time of exposure. This finding give an evidence on the hepatotoxic results observed in this study.

In conclusion, saturn has a potential toxicity hazard in fish and other non-target organisms in the aquatic environment, the matter of which its use as herbicidal agent should be restricted and its escape to fish culture systems should be avoided. 


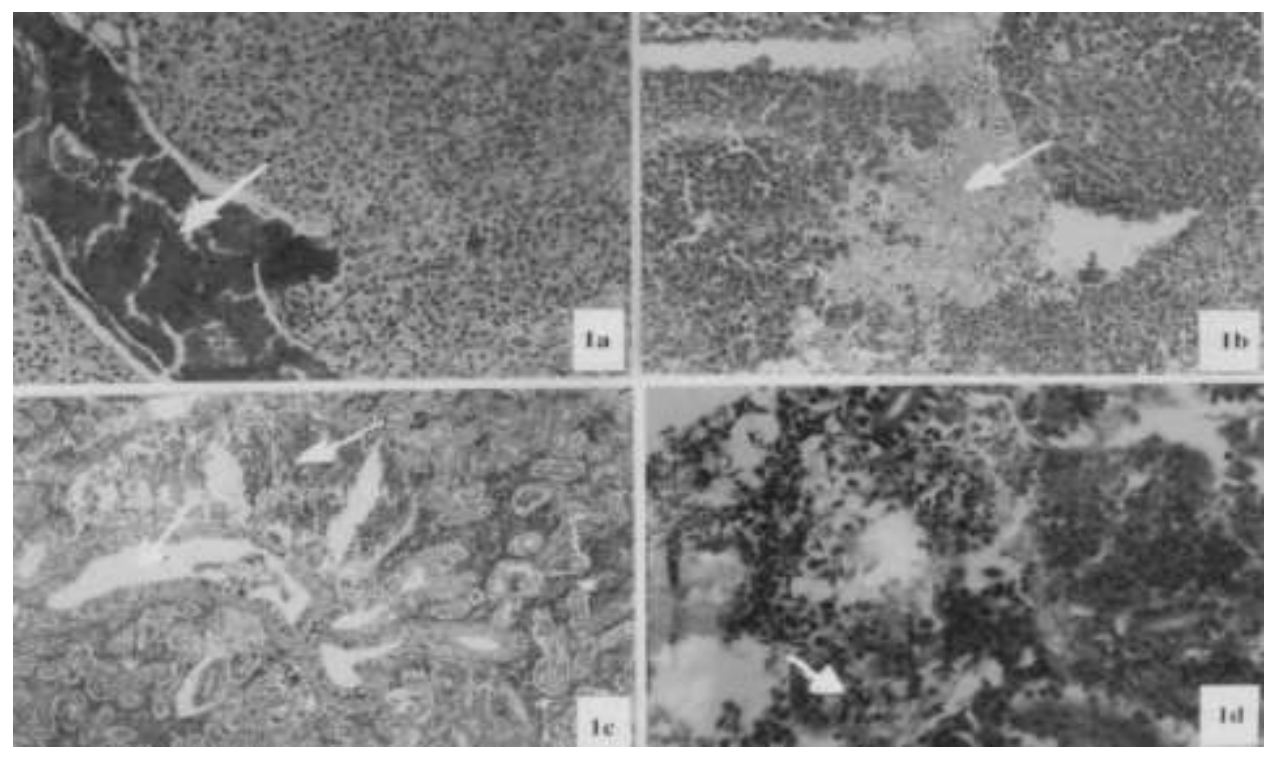

Fig. (1):

(a) Liver of Common carp (Cyprinus carpio L.) exposed to $4.7 \mathrm{ppm}$ Saturn for one week showing congestion of central vein. Notice vacculation of cytoplasm of most hepatocytes (H \& E X 33).

(b) Liver of Common carp (Cyprinus carpio L.) exposed to $4.7 \mathrm{ppm}$ Saturn for one week showing area of haemorrhage dispressing the hepatocytes from each other (H \& E X 33).

(c) Kidney of Common carp (Cyprinus carpio L.) exposed to 4.7 ppm Saturn for one week showing congestion and dilatation of renal blood vessels (H \& E X 33).

(d) Kidney of Common carp (Cyprinus carpio L.) exposed to 4.7 ppm Saturn for one week showing haemohrrages inbetween renal parenchyma. Notice vacuolar degeneration of some renal epithelium (arrow) (H \& E X 66). 

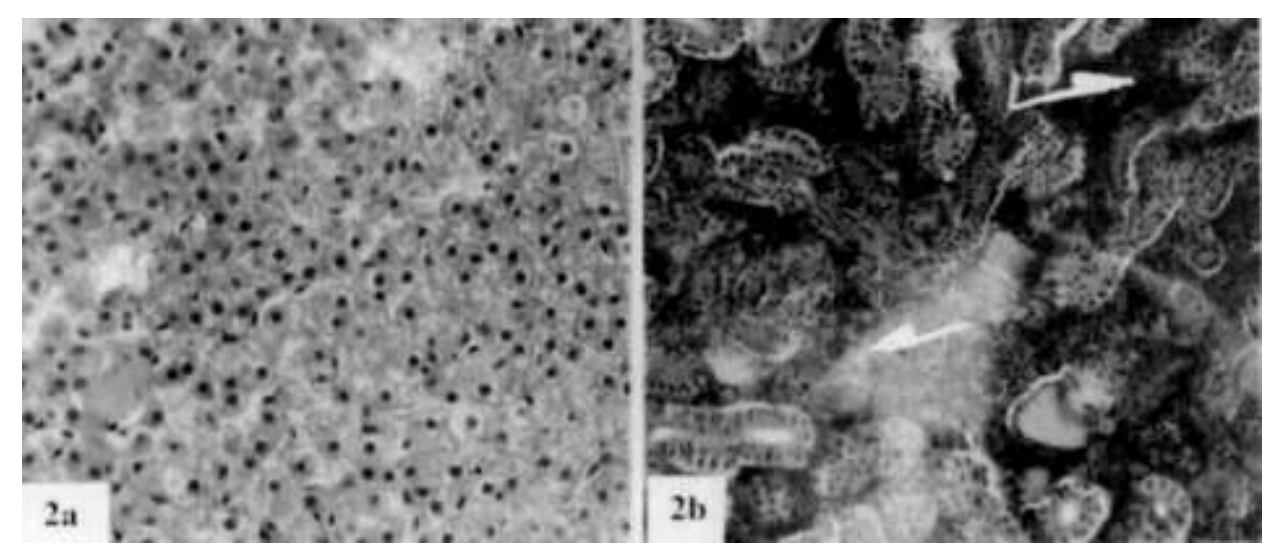

Fig. (2):

(a) Liver of Common carp (Cyprinus carpio L.) exposed to $0.94 \mathrm{ppm}$ Saturn for 6 week showing enlargement and granulation of the cytoplasm of hepatocytes (H \& E X 66).

(b) Kidney of Common carp (Cyprinus carpio L.) exposed to 0.94 ppm Saturn for 6 week showing focal aggregation of mononuclear inflammatory cells in addition to melanophores (arrow) (H \& E X 33).

\section{REFERENCES}

- Abdel-Nasser,M.;Soher,R.A.;Shehata,A.and Ibrahim,T.A. (1991): "Deter-mination of LC50 of pirlmor and novacron on Tilapia nilotica fish."AssuitVet. Med. J., 25 (50): 132-137.

- Abo-Hegab, S.; Kandil, A. and Moharram,N.(1989):"Studies on the effects of exposure of Grass carp(Ctenopharyngodon idella)to several environmental pollutants, change in the blood haematocrit and haemoglobinlevels."Proc.Zoll. Egypt., 17: 237-246.

- Amlacker,E.(1970): “Textbook of fish disease.”T.F.S.Publication, New Jersy, USA, 177-185.

- Anees,M.A.(1975): “Environmental toxicology of pesticides”Pakistan J.Zool., 7:135-136.

- A.O.A.C.(1975): Official of the Association Official Analytical Chemists for determination of pesticide residues.

- Balls, M.; Rosemary, J.; Alastai, R. and Worden, N. (1983):"Animals and alternatives in toxicity testing." Academic Press. A subsidiary of Harcourt Brace Jovanovich, Publishers

$\overline{\overline{\text { Kafr El-Sheikh Vet. Med. J. Vol. } 1 \text { No. } 2 \text { (2003) }}}$ 


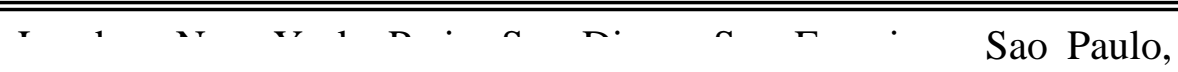

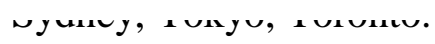

- Bauer, T.D. (1982):“Clinical laboratory methods.” $9^{\text {th }}$ Ed.,PP.580581,C.V. Mosby Co., U.S.A., Biological Trace Element Research Journal, 34 (2): 225-226.

- Couch, J.A. (1975): "Histopathological effects of pesticides and related chemicals on the livers of fishes." In the pathology of Fishes W.E. Ribelin and G. Migaki, (eds), Univ. Wisconsin Press, Madison, Wisconsin, 559-584.

- Cruz, E.R.; De la Cruz, M.C. and Sunaz, N.A. (1988): "Haematological and histopathological changes in Orechromis mossambicus after exposure to the molluscicides aquatin and brestan."The Second International Symposium on Tilapia in Aquaculture Bangkok, Thailand and International Center for Living Aquatic Resources Management, Manila, Philippines, 99-100.

- Dipalma, J.R. (1982): "Basic Pharmacology in Medicine." $2^{\text {nd }}$ ed. pp. 5-8. McGrow-Hill Book Company, New York. San Francisco, London.

- Dortman, R.B. and Lawhorn, G.T. (1978): "Serum enzymes as indicators of chemically induced liver damage.'Drug. Chem. Toxicol., 1 (2): 163-171.

- Eissa, I.A.M. and Fatma,M.F.(1994):"Clinical picture and residue levels of locally used pesticides in some freshwater and marine fishes." Essay in Fish Diseases Dept., Fac. Of Vet. Med., Suez canal Uiniv.

- El-Swak, A.A.; Hussein, Y.A. and Soliman,M.Kh.(1992): "Histopathological changes in carp (Cyprimus carpio L.) intoxicated with Amytrene.'Egypt. J. Comp. Pathol.5 (1): 151-161.

- Evans, O.G.(1996): “Animal Clinical Chemistry.A primer for toxicologists." $1^{\text {st }}$ Ed., pp. 73-98, Great Britain, J.J. Press.

- Faisal, M.; Cooper, E.L.; El-Mofty, M. and Sayed, M.A. (1988): "Immuno-supression of Clarias lazera (pisces) by a molluscicide." Developmental and Comparative Immunology, 12: 85-97.

$\overline{\text { Kafr El-Sheikh Vet. Med. J. Vol. } 1 \text { No. } 2 \text { (2003) }}$ 
- Finney, D.J. (1964): "Statistical Methods in Biological Assay." pp. 528-540. Charles Griffin and Company Limited, London.

- Freeman, H.C.; Sangalang, G.B.; Uthe, J.F.; Garside, E.T. and Daye,P.G. (1983):" A histopathological examination and analvsis for plychlorinated hyd-rocarbons in inshore Atlantic $\mathrm{c}_{\mathrm{C}}$ morhae)."Arch. Environ. Contam. Toxicol., 12: 627-632.

- Fry, F.E.J. (1969): "Some possible physiological stress induced by eutroph-icatin.” Proc. Nat. Acad. Sci., 351: 1696.

- Garcia-Repetto, R.; Martine, D. and Repetto,M.(1995):“Coefficient of dist-ribution of some organophosphorus pesticides in rat tissue." Vet. Human Toxicol.,37(3): 226-229;16ref.

- Halte, H. (1986): "Effect of aluminum in hard, acid water on metabolic rate, blood gas tension and ionic status in the Rainbow trout."J. Fish Biol.,29: 187-198.

- Hansen,D.J.;Parrish,P.R.;Iowe,J.I.;Wilson, A.J. and Wilson, P.D. (1971): "Chronic toxicity, uptake and retention of Archlor 1254 in two estuarinefishes." Bull. Environ. Contam. Toxicol., 6: 113-119.

- Heath, A.G.; Cech, J.J. Jr; Brink, L.; Moberg, P. and Zinkl, J.G. (1987): "Physiological responses of fathead minnow larvae to rice pesticides. "Ecot-oxicol. Environ. Saf.; 37 (3): 280-288.

- Henry, J.B. (1979): "Clinical Diagnosis and Management by Laboratory Methods." Eds. Todd, Saunders, Philadelphia, London, Toronto.

- Johnson,D.W.(1988): "Pesticides and Fishes-a review of selected literature.” Trans. Am. Fish. Soc., 94: 398-424.

- Johnson, G.D.; Palmer, D. A.; Krueger, H.O. and Fischer, D.L. (1993): "Stability of residues and brain cholinesterase activity in carcasses of Northern bobwhite exposed to three organophosphate insecticides."Environ. Toxicol. Chem. 12 (4): 673-676.

- Kachman, J.F. and Moss, D.W. (1976): "Clinical Biochemistry of domestic animals.” Academic Press, Inc. 
- Kaloyanova, F.P. and El-Batawi, M.A. (1991): "Human Toxicology of pes-ticides." $1^{\text {st }}$ Ed., CRC. Press, Inc., Boca, Raton, N.W., Chapter 5, p. 101.

- Kaneko, J.J.; Harvey, J.W. and Bruss, M. (1997):"Clinical Biochemistry of Domestic Animals." 5 ${ }^{\text {th }}$ ed., pp. 407-617, San Diego, London, Boston, New York, Sydney, Tokyo, Toronto.

- Linne, J.J. and Ringsrud , K.M. (1992): "Basic Techniques in

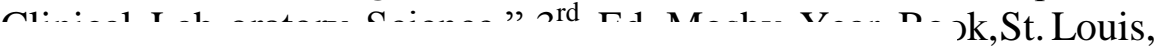

- Marzouk,M.S.M.and Bakeer,A.(1991): "Some investigations in Nile Tilapia exposed to sublethal concentrations of Bayluscid molluscicide.”J.Egypt. Vet. Med. Ass., 51 (1\&2): 97-107.

- Mason,C.F. (1991): "Biology of freshwater pollution.", $2^{\text {nd }}$ Ed., Longman Scientific Technical, pp. 21-41.

- Mayer, F..E.J. (1970): "Seasonal fluctuations in the incidence of disease on fish farms."Symposium on diseases of fishes and shell fishes. P. 21, Special Publication, No. 5, Washington D.C., American Fisheries Society.

- Mazeaud, M.M. (1977): "Primary effects of express in fish, some new data with a general review.”Trans. Am. Fish. Soc., 106: 210.

- Meyer, D.J.; Coles, E.H. and Rich, L.J. (1992): "Veterinary Laboratory Medicine, Interpretation and Diagnosis." 1st ed., pp. 2124, 55-70, 79-81, 135-137, W.B. Saunders Company, Harcourt Brace Jovanovich, Inc., Philadelphia, London, Toronto, Tokyo.

- Miyai,K.(1991): "Structural Organization of the Liver. In Hepatotoxicology." (Meeks, R.G.; Harrison, S.D. and Bull, R.J., ed.) pp. 1-66, CRC Press Boca Raton, Florida.

- Moussa, S.Z.; Abass, H.I. ; Wasfey, M.A. and Aziza, M.M. Amer (1994): 2 "Effect of moluscicide pollutant bayluscid on some blood parameters in Nile catfish (Clarias lazera)."Egypt. Vet. Med. Ass., 54 (5): 885-892.

- Nafady, A.;Shehata,A.;Ibrahim,T.H.A.and Shabaan,A.A.(1986): "Clinical signs,post-mortum findings and histopathological changes

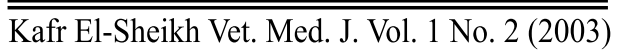


in Tilapia nilotica fish intoxicated with bayluscide."Assuit Vet. Med. J., 17 (34): 126-129.

- Ola, M.H. (1997): "Effect of pollution with pesticides on blood constituents of freshwater fishes." M.V.Sc. Thesis of Clin. Pathology, Egypt. Vet. Med. Cairo University.

- Parums,D.V.(1996): "Essential Clinical Pathology." $1^{\text {st }}$ Ed., pp. $62-$ 72, 430-479, 504-541, Blackwell Science Lts, USA, Canda.

- Petrie,A.and Waston,P.(1999): "Statistics for Veterinary and Animal cience." $1^{\text {st }}$ Ed., pp. 90-99, The Blackwell Science Ltd., United Kingdom.

- Peters, G. (1977): "Zur interpretation des Begriffes fisch." Fisch und UmWelt, 7: 25.

- Plumb,J.A.;Grizzie,J.M.and De Figuriredo,J.(1976): "Necrosis and bacterial infection in channel catfish (Ictalures puntatus)following hypoxia." J. Wild Dis., 12: 247.

- Pluta, H.J. (1989): "Toxicity of several xenobiotics and waster effluents measured with a new fish early life stage test."Germ J. Appl.Zool.,76:195-220.

- Reitman, S. and Frankel, S. (1957): "A colorimetric method for the determ-ination of glutamic oxaloacetic and glutamic pyruvic transaminases.” Am. J. Clin. Path., 28:56-63.

- Safi, J.M.D. (1996): "Liver enzymes as biomarkers of exposure to organop-hosphorus pesticides."Alexandria Sci. Ech., 17 (4): 351360.

- Sastry, K.V. and Sharma, K. (1981): "Diazinon- induced histopathological and haematological alterations in a freshwatrer teleost, (ophiocephalus punc-tatus)."Ecotoxicol. Environ. Safety, 5: 329-340.

- Shaaban, F.E.; Hegazi, A. and Shehata, A.(1980):"Toxicological effects of Diquat on Clarias lazera and Tilapia nilotica- Egyptian Nile fish."Essay in Toxicology Department, Vet. Med., Cairo University, Egypt.

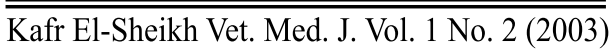


- Shehata, A.; Ibrahim, Th.A. and Shaaban,A.A.(1985):"Acute and subacute toxicity studies of bayluscide in Tilapia nilotica fish.”Assuit Vet. Med. J., 17 (34): 214-220.

- Tressler, K.M. (1988): "Clinical laboratory and diagnostic tests." $2^{\text {nd }}$ Ed., pp. 116-130, Prentice Hall Inc., Engle Wood Cliffs, New Jersey.

- Varley, H.; Gowenlock, A.H. and Bell, M. (1980): "Practical Clinical Bioc-hemistry." Vol. I, $5^{\text {th }}$ ed., William Heinemann edical Books. Ltd. London.

- W.H.O. (World Health Organization) (1985): "Interpretation programme on chemical safety Environmental Health Criteria for organophosphorus insect-icides." Cinebra.

- Zimmerman H.J. and Henry J.B.(1989): "Clinical Enzymology." In Henry J.B. (eds) : "Clinical Diagnosis and Management by Laboratory Methods." $18^{\text {th }}$ ed. pp. 251-282. Marriam and Webster Inc. Manila Philinnines W.B. Saunders Comnanv. Philadelphia.

$$
\begin{aligned}
& \text { بعض الأبحاث على الساترن (مبيد عشبى) على أسماك المبروك } \\
& \text { العادى } \\
& \text { المستزر ع فى محافظة كفر الثيخ } \\
& \text { محمد سعيد جادو ، عصام الدين كامل أحمد ، دعاء محمد جاد عبد العظيم } \\
& \text { تم دراسة تأثير مبيد الحشائش من مجموعة الكربامات المعروف باسم الساترن،على صحة } \\
& \text { أسماك المبروك العادى والمستزرعة فى محافظة كفر الثيخ. دئ. } \\
& \text { - تم تحديد التركيز المييت (LC 50) من الساترن لأسماك المبروك،وقد وجد أنه } 9.4 \text { من } \\
& \text { المليون/48 ساعة. }
\end{aligned}
$$


- تم تعريض مجموعة من الأسماك لنصف وعشر الجرعة النصف ممينة من المبيد لمدة سبعة أيام

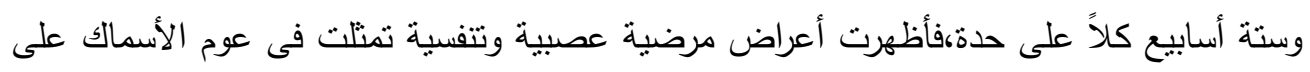
سطح الماء وابتلاع الهواء الجوى والحركة السريعة لغطاء الخياشيم واختلال طريقة العوم.

- أظهرت نتائج الاختبارات البيوكيميائية على مصل دم اسماك المبروك المعرضة للمبيد وجود زيادة معنوية فى نشاط أنزيمات الكبد منل الاسبرتات أمينو نرانس فيريز (AST) ،والالانين أمينو ترانس فيريز (ALT)،والالكالين فوسفاتيز (ALP) طوال فترة التجارب.

- أظهرت الفحوص الهسنوباثولوجية لأسماك المبروك التى تعرضت للمبيد،وجود تغيرات مرضية خلوية فى الأعضاء المختلفة مثل الكبد والكلى.

- أنتتت نتائج تحليل أنسجة عضلات وكبد الأسماك المعرضة لتركيزات مختلفة من المبيد،وجود بقايا المبيد فى هذه الأنسجة بنسب تتتاسب مع تركيز المبيد فى المياه وفترة تعرض الأسماك لها. 